\title{
BARBÁRIE E EXCEÇÃO: O DESVELAMENTO DO PARADIGMA DA ATUAÇ̃̃O DO DIREITO PELA LITERATURA DE TESTEMUNHO DE PRIMO LEVI
}

\author{
Diogo VAlério FéliX ${ }^{1}$
}

\begin{abstract}
RESUMO: O presente trabalho tem por finalidade apresentar um debate sobre o paradoxo do estado de exceção, como estrutura de significação do direito de governança, em uma aproximação entre o direito e a literatura pelo método dedutivo, tendo a fonte de investigação teórica apoio na pesquisa bibliográfica. Para tanto, a análise se inicia com o relato de Primo Levi, um literato italiano sobrevivente de Auschwitz, no sentido de demonstrar em que medida a literatura de testemunho ilustra a existência e a condição do campo de concentração e de seu vivente como uma situação normativamente paradoxal, capaz de proporcionar, inclusive, a destruição completa das subjetividades humanas. Dentro dessa perspectiva, acompanhando a leitura de Giorgio Agamben, o artigo apresenta uma genealogia do direito com supedâneo no instituto do "bando", em contraposição à teoria do contrato social, enquanto matriz teórica e paradigma do Direito. Assim o campo de concentração, na forma da exceção, revelase em uma estrutura originária na qual o direito se refere à vida, e a inclui em si através de sua própria suspensão, fazendo por concluir que o "campo", de forma espectral, é o resultado da operação do direito e da política via dispositivo de captura.
\end{abstract}

Palavras-chave: direito; bando; estado de exceção; campo de concentração.

\section{INTRODUÇÃO}

$\mathrm{O}$ século $\mathrm{XX}$ demonstrou, em termos históricos, uma série de fenômenos que elevaram a problematização acerca da fundamentação e a tutela dos direitos humanos, sobretudo em razão de sua relação com a Política, no sentido de se buscar uma teorização para o entrelaçamento das

1 Mestre em Ciências Jurídicas pelo Centro Universitário de Maringá (UNICESUMAR). Graduado em Direito pelo Centro Universitário de Maringá (UNICESUMAR). Professor do Curso de Direito da Faculdade Cidade Verde (FCV). Maringá (PR), Brasil. CV Lattes: http://lattes.cnpq.br/7549347112132551. ORCID: https://orcid.org/o000-0003-17727620. E-mail: adv.diogofelix@hotmail.com. 
respectivas dimensões da vida social, exigindo uma abordagem genealógica quanto ao reconhecimento e tutela das garantias jurídicas entendidas como “essencialmente” - supra histórica - humanas.

Nesse sentido, a história revela que o reconhecimento de direitos entendidos como inatos e inalienáveis do homem, cujo fundamento se apara na natureza humana, não se mostram suficientes à tutela do ser humano, na medida em que, ainda hoje, no século XXI, observam-se grandes conglomerados de seres humanos desprovidos de tais direitos, tal qual acontecem com os imigrantes e os campos de refugiados espalhados ao longo do globo.

Assim, um debate sério, não só quanto à efetividade dos direitos humanos, mostra-se necessário, mas, inclusive, da própria figura do sujeito de direito, envolvendo a discussão acerca do Direito e da Política, debate esse que será realizado por intermédio do método dedutivo, e com apoio da pesquisa bibliográfica como fonte de investigação teórica. Para tanto, a presente pesquisa contará com o apoio da literatura de testemunho, em especial a obra de Primo Levi, um dos sobreviventes do mais bárbaro dos campos de concentração da segunda guerra mundial, qual seja: Auschwitz, o que nos leva a questionar, não só sobre a perspectiva dos direitos humanos e do sujeito de direito, mas, inclusive, sobre o papel do direito neste trágico episódio da história humana.

Assim, o artigo se inicia com o "testemunho" do autor italiano quando de sua estada no campo de extermínio, revelando, inclusive, o descrédito da população quanto às práticas exercidas nos respectivos campos.

Nesse primeiro movimento, o artigo apresenta a relação entre o direito e a literatura, e, em especial, a literatura de testemunho, a fim de demonstrar a problematização quanto aos campos de concentração e suas consequências epistemológicas no que diz respeito à representação do homem e do direito enquanto categorias jurídico-políticas, verificada no "testemunho" de Primo Levi.

Avançando no texto, o segundo movimento visa uma relação entre o testemunho e a memória, no sentido de apresentar o homem àquele "animal" capaz de prometer, no sentido de tornar possível a disposição de si próprio, e, assim, responder por si mesmo no futuro. A memória, em especial a de Auschwitz, em termos históricos, políticos e jurídicos, mostra- 
se semelhante a condição epistemológica, em termos de saber jurídico acerca da relação das categorias do humano, do político e do jurídico.

No terceiro movimento, dada a problematização construída em torno das categorias jurídica e do humano, o artigo avança no intuito de buscar sentido aos campos de concentração enquanto um espaço de exceção normativa, identificando o "campo" tal qual uma zona ambígua em termos representação e significado, em que se verificam a existência de seres humanos que não dispõem de direitos humanos, configurando, assim, um paradoxo, demonstrando, ainda, a caracterização dos campos de extermínio da figura mais extremada desse paradoxo, fixando-o ao mesmo patamar de um paradigma da atuação do jurídico-político na sociedade contemporânea.

Ao final do artigo, há a abordagem quanto ao papel do direito no que se refere aos campos de concentração na sua forma espectral do estado de exceção, apontando o direito, a partir do paradigma da soberania, em que medida o dispositivo que opera a partir da exceção em uma atuação de exclusão do vivente do circuito jurídico e sua consequente inclusão nos cálculos de poder.

No mais, cumpre, desde já, esclarecer que o presente trabalho não tem por finalidade construir uma (boa ou má) resposta para os questionamentos levantados no texto, nem mesmo esgotar qualquer discussão acerca da temática envolvida, mas, fazer uma aproximação de toda experiência vivida pelo autor italiano, expressada pela literatura de testemunho, da violência sofrida na sua mais ampla concepção.

\section{O TESTEMUNHO: O DESCRÉDITO DA BARBÁRIE E DO HORROR DO LAGER}

A utilização da obra de Primo Levi, no presente estudo, enquanto recurso literário, tem o intuito de demonstrar em que medida a literatura nos leva a questionar, em termos poéticos, ou seja, de autorreflexão, sobre as categorias jurídicas e políticas que promovem a definição do homem como sujeito de direito, em um dos mais trágicos episódios da história humana, a saber: os campos de extermínio nazistas.

O movimento direito e literatura apresenta interessantes contribuições e abordagens no que diz respeito aos discursos e, em especial, ao discurso normativo, no sentido de buscar uma abordagem da lei por 
intermédio da literatura, a fim de alcançar a compreensão do jurídico e sua linguagem (Ramiro, 2012, p. 297).

Assim, segundo o Professor Roberto Bueno (2011, p. 10):

A literatura é um instrumento promissor, provavelmente mais do que a filosofia, quando temos em perspectiva um processo de autorreferenciação. Essa autorreferenciação deriva do processo de reconstrução de nós próprios a partir de nossa ocupação em reconstruir nossos léxicos, algo que repetidamente se faz necessário porque vivemos em situação de contingência, vale dizer, transitoriedade ou historicidade.

É nesse sentido, que a literatura, e sua aproximação com o direito, se apresenta, conforme as lições de Pietroforte (2002, p. 32), assim como discurso poético que opera a partir de formas de linguagem capazes de revelar a complexidade que existe entre os que fazem a lei e os que a sofrem, trazendo à tona toda a problemática acerca do sujeito de direito vivenciada e "testemunhada" por Primo Levi.

O debate acerca do sujeito de direito encontra ecos na literatura, em uma autorreflexão, no sentido de demonstrar, a partir da obra de Primo Levi, que o titular dos direitos humanos não se afigura na mera condição de ser humano, mas em uma circunstância eminentemente política, no sentido de que a tutela dos respectivos direitos exige a condição de sujeito político, ou seja, de cidadão, apontando, assim, o "campo" como a situação limite, e, portanto, paradigmática, que define a titularidade de direitos humanos e fundamentais, afastando toda e qualquer ideia de que a natureza, ou, essencialidade, dentro de uma perspectiva espaço temporal, seja capaz de fixar a titularidade de direitos.

Assim, o "testemunho" de Primo Levi se mostra fundamental na busca da constatação sobre a identificação do "sujeito de direito" em uma condição excepcional, onde o ordenamento jurídico, apesar de vigente, encontra-se suspenso, dada a impossibilidade de fixação, a priori, da sua condição jurídica.

Do ponto de vista teórico há um consenso de que a literatura de testemunho, utilizada na presente pesquisa, associa-se diretamente sobre a reflexão quanto a exclusão social, motivo pelo qual os discursos críticos que estabelecem separações rígidas entre a literatura e a história, podem ser rediscutidos, em razão de uma integração necessária que o testemunho, 
enquanto objeto de investigação, solicita entre os campos das duas disciplinas (Ginzburg, 2008).

A literatura de testemunho tem sua origem no fenômeno jurídico, uma vez que remete etimologicamente à voz que toma parte de um processo, em situação de impasse, e que pode contribuir para desfazer uma dúvida (Ginzburg, 2008). Além disso, o termo testemunho, segundo as lições de Seligmann (2003, 378), associa-se na tradição da figura do mártir, o sobrevivente de uma provação, que aponta, em ambos os casos, uma fala em tensão com uma realidade conflitiva.

É nesse sentido que a obra de Primo Levi apresenta um duro e chocante relato, não de sobrevivência, mas de toda experiência vivida no mais bárbaro dos campos de concentração da segunda guerra mundial, qual seja, Auschwitz. O testemunho, ou seja, o supertite ${ }^{2}$, desde as primeiras classificações dos prisioneiros pelo estado nazista, da subjugação nas viagens, da "existência" no Lager (campo de concentração), do processo de destruição da vida, que demonstra toda a problemática envolvendo a relação entre o homem e o direito como instrumento de gestão da vida social, a partir de uma situação eminentemente paradoxal, a saber: o campo $^{3}$, que na presente pesquisa, é abordado pelos campos de extermínio caracterizados em um espaço de exceção normativa, a partir da aproximação entre Direito e Literatura.

A temática proposta nos leva a questionar a natureza humana, não só em uma extensão conceitual, mas, em especial, em uma dimensão ontológica, cabendo aqui a constatação do Professor Oswaldo Giacoia Júnior, no que concerne ao pensamento sobre a natureza humana, que nenhum objeto corresponde a um sujeito genérico, cujas disposições ontológicas tornar-se-iam efetivas, no tempo e na história, ao longo de uma trajetória progressiva virtualmente infinita, sobretudo na era da dominação planetária da tecnociência, em que a biologia molecular e a engenharia

2 O termo significa, conforme esclarecido por Giorgio Agamben (2008, p. 27), etimologicamente, aquele que viveu algo, atravessou até o final um evento e, pode, portanto, dar testemunho disso.

3 Segundo Giorgio Agamben, o campo se apresenta como forma legal daquilo que não pode ter forma legal, ou seja, um espaço de exceção normativa-jurídica, onde se apresenta como dispositivo original ao qual o direito se refere a vida e a inclui em si por meio de sua própria suspenção, revelando uma relação que liga e, ao mesmo tempo, abandona o vivente ao direito, apresentando-se, portanto, como um paradoxo (Agamben, 2004, p. 12). 
genética, tornam-se paradigmas de racionalidade, instrumentalizando a base somática da personalidade humana (Giacoia Jr., 2013, p. 21).

Sobre a barbárie nos campos de concentração e da ignorância deliberada e descrédito sobre os mesmos, Levi descreve que as notícias sobre os campos nazistas eram vagas, e delineavam um massacre de proporções tão amplas, de uma crueldade tão extrema, de motivações tão intrincadas que o público tendia a rejeitá-las em razão de seu próprio absurdo (Levi, 2004, p. 9).

A negação sobre o horror dos campos era avisado, cinicamente, pelos próprios soldados $S S$ aos prisioneiros, conforme o relato de Simon Wisenthal:

"seja qual for o fim desta guerra, a guerra contra vocês
nós já ganhamos; ninguém restará para dar testemunho,
mas, mesmo que alguém escape, o mundo não lhe dará
crédito. Talvez hajam suspeitas, discussões, investigações
de historiadores, mas não haverá certezas, porque
destruiremos as provas junto com vocês. E ainda que
fiquem algumas provas e sobreviva alguém, as pessoas
dirão que os fatos narrados são tão monstruosos que não
merecem confiança: dirão que são exageros da
propaganda aliada e acreditaram em nós, que negaremos
tudo, e não em vocês. Nós é que ditaremos a história dos
Lager - campos de concentração (Levi, 2004, p. 9).

Hannah Arendt, ao descrever sobre o julgamento de Eichmann em Jerusalém, que uma das testemunhas do julgamento relatou que as pessoas se apresentavam voluntariamente para a deportação de Theresienstadt para Auschwitz e denunciavam "insanas" aquelas que tentavam lhes dizer a verdade sobre o horror que lá ocorria (Arendt, 1999, p. 135).

Salmen Lewental (apud Agamben, 2008, p. 20), um membro do Sonderkommando, confiou seu testemunho em algumas pouquíssimas linhas, que "nenhum ser humano pode imaginar como ocorreram precisamente os acontecimentos, e, de fato, é inimaginável que possam ser descritas exatamente como aconteceram nossas experiências”.

A dimensão da violência e do horror perpetrado nos Lager, conhecida apenas no testemunho, e até hoje muitas vezes negado, extrapola os limites da extensão física e psicológica do prisioneiro, na medida em que, ao final do "processo", a consequência é a expropriação da vida do ser, de sua alma, ou seja, a destruição do homem. 
Em verdade, segundo a descrição do Professor Roberto Bueno, a violência transforma, marca, a violência profunda, esta enrudece, entorpece, rudimentariza e paralisa, enquanto a violência organizada descontrói e desfigura as subjetividades humanas, e ao retirar-lhes suas próprias almas em vida, tende a nadificá-las (Bueno, 2012, p. 471-498). E, de igual modo expressa a voz emprestada ao testemunho, "custou, levou tempo, mas vocês alemães conseguiram” (Levi, 1988). Tal destruição tem a ver com a negação do homem perante si mesmo e os demais. A destruição física, ou seja, a do corpo, é mera consequência de todo o processo.

\section{3 É ISTO UM HOMEM?}

Ao fazer o relato de sua experiência no campo de concentração Lager, Primo Levi, para satisfazer uma necessidade pessoal e declarada de libertação interior de todo o trauma vivido, que jamais o abandonou em vida, inicia a obra $E$ isto um homem? com um poema de cunho sombrio, e no mínimo perturbador, a fim de preparar o leitor para uma experiência, infinitamente menor, mas também traumática, de um relato, não apenas sobre Auschwitz, mas principalmente, sobre o próprio homem:

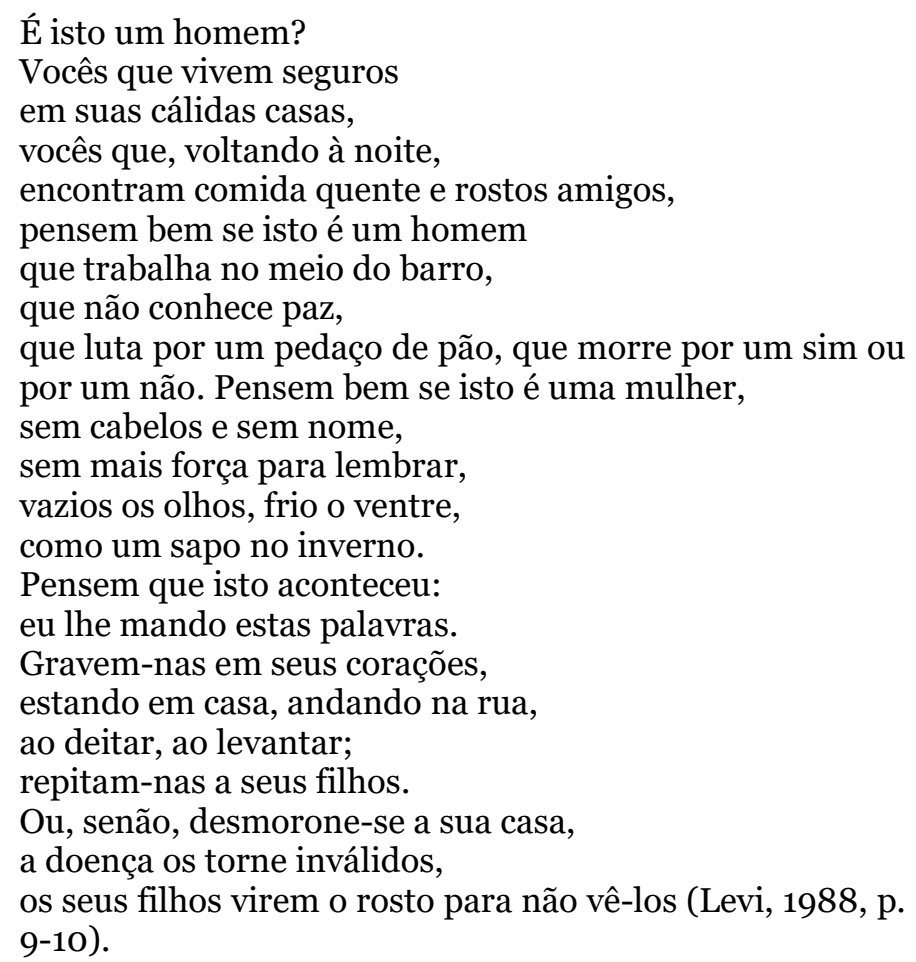

O sedicioso questionamento, quase, senão é, uma maldição, é o retrato do encontro do autor com o homem lançado à margem de toda a 
exceção, do sujeito desprovido não só dos bens que lhe atribuem personalidade e dignidade, mas, inclusive, do último fio capaz de conduzi-lo a uma consciência minimamente moral, subjetiva, que o individualiza e o distingui enquanto Ser vivente e resultante de um processo fenomênico, ocasionando a perda consciente do encontro do Ser, enquanto indivíduo, com ele mesmo, e que gera um trauma e uma negação quanto à identificação de $S i$ no $S e r$, um espelho que revela toda a sua constituição, o que há de mais íntimo e individual, a causa de sua maior vergonha, a nudez de toda a vida.

"É isto um homem? [...] Pensem que isto aconteceu [...] Gravem-na em seus corações" - É inegável a proposta lançada por Levi no que se refere à memória da barbárie vivida; da memorização traumática e irremediável que aflige sua alma mesmo após a libertação, e que é causadora de sua maior culpa, a de ter sobrevivido, a de ter conhecido a mais funda das dimensões do homem, no limiar entre o homem e a mera vida, da nudez causada pela maior violência possível, a expropriação da alma, e que é causadora da lembrança, qual seja, a memória.

O encontro com o horror testemunhado por Levi causa o trauma que gera a memória necessária para que nos lembremos do que o homem é, e do que ele pode se tornar, portanto, "vocês que vivem seguros", vocês que não experimentaram o horror que a barbárie por causar, do que a barbárie pode transformar, do que a violência pode descontruir, "pensem que isto aconteceu, gravem-na em seus corações”.

Nietzsche, em Para a genealogia da moral, formula suas ficções heurísticas sobre a pré-história da hominização vinculando memória e o esquecimento, com faculdades determinantes do vir-a-ser humano. De acordo com o filósofo, o hominídeo torna-se humano pela criação e uma memória da vontade, escandindo as dimensões do passado, presente e futuro, e tornando possível tanto a previsão quanto a rememorização. A invenção da memória provê as condições de possibilidade de uma faculdade de simbolização, que arranca do bicho-homem de sua condição de animal, ligada aos efeitos atuais (presentes) da percepção sensível. O humano é o único animal capaz de prometer, faculdade que pressupõe uma memória da vontade, e esta, por sua vez, torna possível dispor de si próprio, responder por si mesmo no futuro (apud Giacoia Jr., 2013, p. 28). 
"É isto um homem? [...] Pensem que isto aconteceu [...] Gravem-na em seus corações" - Cumpre-nos trazer, aqui, a questão levantada por Oswaldo Giacoia Júnior (2013, p. 28) em Nietsche: o humano como memória e como promessa, sobre a criação dessa faculdade a partir da instrumentalização da violência empregada contra o próprio homem, associada a representação de valor, "como imprimir algo nesse entendimento de instante, entendimento em parte obtuso, em parte aturdido, nessa vivente capacidade de esquecimento, de tal maneira que permaneça presente?”. Ou seja, como construir uma memória futura, um entendimento valorativo, diante da capacidade de esquecimento? Se valendo das lições de Nietzsche, o filósofo brasileiro conclui que para que algo permaneça na memória, grava-se-o a fogo; somente quando o que não sessa de causar dor permanece na memória (Giacoia Jr., 2013, p. 28-29).

Segundo, ainda, o Professor Giacoia (2013, p. 29-30):

A tecnologia necessária para implantar a própria memória da vontade consiste na instrumentalização da dor - não se trata meramente de providenciar que alguns preceitos permaneçam na memória já dada, ainda que apenas in potentia. Antes, o próprio registro da memória veio-a-ser, e esse devir tem bases psicológicas fisiológicas. Ele foi gravado a fogo no sensorium do animal homem. Somente por meio de uma dor que não cessa permanece a memória, e assim torna-se possível que algo inscreva-se, como preceito, nesse tecido calcinado da memória humana. [...] Tais constantes antropológicas condicionam a humanitas do homo humano: uma memória da vontade forjada à contracorrente da poderosa força animal do esquecimento; e uma capacidade de prometer, de fazer-se responsável.

É diante dessa capacidade de esquecimento, que o literato italiano esclarece que as recordações da experiência testemunhada não estão escritas na pedra; não só tendem a apagar com os anos, mas muitas vezes se modificam ou mesmo aumentam, revelando, assim, uma inconfiabilidade das recordações. Esta escassa confiabilidade só será aplicada de modo satisfatório quando soubermos em qual língua, em qual alfabeto elas serão escritas, sobre qual material, com qual instrumento (Levi, 2004, p. 19).

Portanto, o "desabafo" inicial de Levi, ao questionar se é isto um homem, propõe uma promessa; "vejam o que somos, vejam o que podemos fazer; carreguem isso na memória, ou perderemos a nossa própria alma ainda em vida". 


\section{A AMBIGUIDADE DA VIOLÊNCIA: A ZONA CINZENTA}

A cor cinza indicada por Levi trata-se de uma representação da vida do Lager, que nos anos vividos no campo a vida tornou-se cinzenta. Simbolicamente, a cor cinza também exerceu seu papel, afinal, aproximanos à mesma que sombriamente emergia das chaminés dos fornos crematórios nos campos de concentração nazistas. Em ato sinistro subsequente ao terror, encobria os campos de concentração e jogava sob os parentes e amigos sobreviventes os plúmbeos restos dos violentamente trucidados (Bueno, 2012, p. 471-498).

É diante dessa zona cinzenta que Levi descreve que não eram simples as relações humanas no interior do Lager, mas uma nebulosidade incompreensível, cinzenta, não podendo reduzi-las a dois blocos, os das vítimas e dos opressores. Segundo o escritor, em que lê (ou escreve) hoje a história do Lager é evidente a tendência, ou melhor, a necessidade de dividir o bem e o mal, de poder assumir um lado, de repetir o gesto do Cristo no Juízo Universal: aqui os justos, lá os réprobos (Levi, 2004, p. 32).

Giorgio Agamben, em sua obra $O$ que resta de Auschwitz, em análise à "zona cinzenta”, classifica-a como

aquela da qual deriva a longa cadeia de conjunções entre vítimas e algozes, em que o oprimido se torna opressor e o carrasco, por sua vez, aparece como vítima. Trata-se de uma alquimia cinzenta, incessante, na qual o bem e o mal e, como eles, todos os metais da ética tradicional alcançaram o seu ponto de fusão. Trata-se, portanto, de uma zona de irresponsabilidade e de impotente judicandi, que não se situa além do bem e do mal, mas que esta, por assim dizer, aquém dos mesmos. [...] Essa infame zona de irresponsabilidade é o nosso primeiro círculo do qual confissão alguma nos conseguirá arrancar e no qual, minuto após minuto, é debulhada a lição da temível banalidade do mal, que desafia as palavras e pensamentos (2008, p. 30-31).

Essa violência, representada não só pela cor cinza, mas, sobretudo pelos corpos e almas massacrados pela vida no campo, representa, ao mesmo tempo, o indizível da banalidade do mal, nos moldes apresentados por Hannah Arendt, no caso Eichmann, que, no Lager, se apresenta desde as relações mais simples, pautadas na espera do afago pelo seu igual em condição de oprimido, às mais complexas, refletida na busca pela sobrevivência, e, como um hiato, o sofrimento da mais profunda violência representada pelas agressões dos mesmos iguais. 
A chegada no Lager é marcada pela ausência da ambiguidade entre os prisioneiros e os aprisionadores, entre a vítima e o opressor, que, apesar da terrível experiência do campo, haveria um afago ao encontrar aquele que estava na mesma condição de prisioneiro, de vítima, afago este trazido pela leitura das relações, pela possibilidade de encontrar um mundo terrível, mas decifrável (Levi, 2004, p. 32).

Sobre o ingresso no Lager, Primo Levi (2004, p. 32-33) relata que:

[...] constituía um choque em razão da surpresa que implicava. O mundo no qual se precipitava decerto era terrível, mas também indecifrável: não era conforme nenhum modelo, o inimigo estava ao redor, mas também dentro, o "nós" perdia seus limites, os contendores não eram dois, não se distinguia uma fronteira mas muitas vezes confusas, talvez inúmeras, separando cada um do outro. Entrava-se esperando pelo menos a solidariedade dos companheiros de desventura, mas os aliados esperados, salvo casos especiais, não existiam; existiam ao contrário mil mônodas impermeáveis e, entre elas, uma luta desesperada, oculta e contínua. Esta revelação brusca, que se manifestava desde as primeiras horas de cativeiro, muitas vezes sob a forma imediata de uma agressão concêntrica por parte daqueles em que se esperava encontrar os futuros aliados, era tão dura que logo derrubava a capacidade de resistir. Para muitos foi mortal, indiretamente ou diretamente: é difícil defenderse de um golpe para o qual não se está preparado, qual seja, da violência dos iguais em cativeiro.

Observa-se, assim, que toda a sistemática do Lager é organizada no sentido de acabar com toda e qualquer possibilidade de resistência de seus "viventes", na medida em que esses se deparam com um "universo" indecifrável; visível aos olhos, mas desprovido de qualquer sentido; impossibilitando a continuidade da vida para além das ordens dos $S S$, e de qualquer esboço de resistência, dada à violência perpetrada pelos próprios prisioneiros, os Sonderkommandos (unidades especiais compostas pelos próprios prisioneiros "colaboradores"), não apenas no ao âmbito material, ou seja, às suas ordens, mas, sobretudo, na perspectiva moral, tendo em vista a incapacidade de resistir ao desejo de estar em condição privilegiada, ou seja, na condição de agressor, onde a dor, a fome e a sede são, por assim dizer, amenizadas, tornando-se, desta forma, um sistema aquém do bem e mal, um mundo nebuloso, opaco, cinza. 
O destino normal de um prisioneiro era apenas um: a morte. De modo macabro, encontrava-se escrito no portal de entrada de Auschwitz, Arbeit macht frei (o trabalho liberta). De fato, ainda que não se leve em conta o cansaço, os golpes, o frio, as doenças, deve-se lembrar que a alimentação era nitidamente insuficiente. Gastas em dois ou três meses as reservas fisiológicas do organismo, a morte por fome, ou por doenças causadas pela fome, era um destino certo aos prisioneiros, que poderia ser evitada, apenas, com um suplemento alimentar, ou seja, com uma porção extra da ração alimentar, e para obtê-lo era preciso um privilégio, grande ou pequeno, em outras palavras, um modo astuto ou violento, lícito ou ilícito de estar acima da norma do campo (Levi, 2004, p. 35).

Sim, a violência partia daqueles que ocupavam o status de prisioneiro-funcionário, daquele que é, ao mesmo tempo, vítima do sistema nazista e servidor do mesmo, daquele que se mostra igual em condição de prisioneiro, de vítima,

que ao invés de pegar a mão, tranquiliza-lo, ensinar-lhe o caminho, se arroja sobre o Zugang (novato), gritando ordens em uma língua desconhecida e lhe golpeia o rosto. Ele quer domá-lo, quer apagar a centelha de dignidade que talvez o "novato" ainda conserve, e que ele perdeu. $\mathrm{O}$ privilégio, por definição, defende e protege o privilégio, de modo que todo e qualquer sinal de reação, pode levar a morte, uma vez que a resposta na mesma moeda é uma transgressão intolerável, e que só pode ocorre a um "novato" (Levi 2004, p. 35).

Cumpre destacar, que a condição de prisioneiro privilegiado, acabava por atrair, quase que necessariamente, aqueles prisioneiros que de algum modo apresentavam alguma característica favorável ao sistema, uma potencialidade de colaborador em prol de uma possibilidade de sobrevivência (sobrevida - vida além da norma do campo). Muitos buscavam esse poder espontaneamente, esses eram os sádicos, temidos no campo, uma vez que para eles a posição de privilégio coincidia com a possibilidade de infligir aos subordinados sofrimento e humilhação.

Os Sonderkommandos, nos dizeres de Agamben, representa a figura extrema da zona cinzenta, que é o campo de concentração, na medida em que, conforme o testemunho de Primo Levi (2004, p. 43), a esses, era atribuída a função da gestão das câmaras de gás e dos fornos crematórios. Toda a preparação, até a execução das mortes eram atribuições dos 
Sonderkommandos. "Eles deviam levar os prisioneiros nus à morte nas câmaras de gás e manter a ordem entre os mesmos" (Levi, 2004, p. 43); “depois de arrastar para fora os cadáveres, manchados de rosa e de verde, em razão do ácido cianídrico, lavando-os com jatos de água; verificar se os orifícios dos corpos não estavam escondidos objetos preciosos" (Agamben, 2008, p. 34); "arrancar os dentes de ouro dos maxilares; cortar os cabelos das mulheres" (Levi, 2004, p. 43) "e lavá-los com cloreto de amônia; transportar depois os cadáveres até os fornos crematórios; e, finalmente, tirar as cinzas residuais dos fornos" (Agamben, 2008, p. 34).

Levi relata:

Sobre esses Esquadrões, boatos vagos e truncados já circulavam entre nós durante o confinamento e foram confirmados mais tarde [...], mas o horror intrínseco dessa condição humana impôs a todos os testemunhos uma espécie de pudor; por isso, ainda hoje é difícil construir uma imagem do que "significava" ser forçado a exercer esse ofício durante meses. [...]. Um deles declarou: "Ao fazer este trabalho, ou se enlouquece no primeiro dia, ou então se acostuma". Mas outro disse: "Por certo, teria podido matar-me ou me deixar matar; mas eu queria sobreviver, para vingar-me e para dar testemunho. Vocês não devem acreditar que somos monstros: somos como vocês, só que muito mais infelizes". [...] Ter concebido e organizado os Esquadrões foi o delito mais demoníaco do nacional-socialismo (2004, p. 45).

Essa violência organizada, sistematizada, de natureza tão sombria, que acabou por atingir não só as dimensões físicas do corpo, mas, também, no psicológico dos integrantes do campo, dado o colapso moral vivenciado, subtraindo, assim, toda a subjetividade humana, ocasionando a expropriação da própria alma, ainda em vida, pois "os judeus é quem deveriam por nos fornos os judeus, devia-se demonstrar que os judeus, subraça, sub-homens, se dobram a qualquer humilhação, inclusive a destruição de si mesmos" (Levi, 2004, p. 44).

Segundos as revelações de Levi, em ambos os casos, quais sejam, aqueles que ocupam o status de privilegiado para escapar da "solução final”, seja para atendimento e satisfação de um sadismo, o poder é concedido generosamente a quem esteja disposto a reverenciar a autoridade hierárquica, conseguindo, assim, uma promoção social inalcançada de outro modo (Levi, 2004, p. 35). 
Há de se destacar, que a busca pelo privilégio não ocorria apenas dentro do Lager, na medida em que a busca pela salvação da "solução final" se dava, também, fora dos campos de concentração, também na figura dos Sonderkommandos, compostos por "judeus colaboradores" do regime nazista, a fim de salvar a si próprios da morte imediata, e os Conselhos de Anciões Judeus, que de certo modo, atuaram no sentido de "evitar" consequências mais 'sérias' do que aquelas ocorridas (Arendt, 1999, p. 106107).

Ao descrever o julgamento de Eichmann em Jerusalém, um dos oficiais do estado nazista, no que toca a colaboração dos próprios judeus na “solução final”, Hannah Arendt (1999, p. 133) relata que:

Eichmann contou que o fator mais potente para acalmar a sua própria consciência foi o simples fato de não ver ninguém, absolutamente ninguém, efetivamente contrário à Solução Final. Ele encontrou uma exceção [...]. Foi na Hungria, quanto ele estava negociando com o dr. Kastner a oferta de Himmler de libertar um milhão de judeus em troca de 10 mil caminhões. Kastner, aparentemente fortalecido pelo novo rumo das coisas, pediu a Eichmann que parasse "os moinhos de morte de Auschwitz", e Eichmann respondeu que o faria "com o maior prazer", mas que infelizmente isso estava fora de sua alçada e fora da alçada de seus superiores como de fato estava. Evidentemente, ele não esperava que os judeus compartilhassem o entusiasmo geral por sua destruição, mas esperava um pouco mais de complacência. Esperava - e recebeu, a um ponto verdadeiramente extraordinário - a cooperação deles. Isso era "evidentemente, a pedra angular" de tudo o que se fazia [...]. Não fosse a ajuda judaica no trabalho administrativo e policial - o agrupamento em Berlim foi [...] feito inteiramente pela polícia judaica -, teria ocorrido ou o caos absoluto ou uma drenagem extremamente significativa do potencial humano alemão. ("Não há dúvida de que, sem a cooperação das vítimas, dificilmente teria sido possível para uns poucos milhares de pessoas [...] ao longo de todo o caminho para as suas mortes, os judeus poloneses não viam mais do que um punhado de alemães."[...].

Veja-se, que a "extraordinária” e mortífera sistemática administrativa e policial do estado nazista imprimiu uma completa incapacidade de resistência não só aos "ataques" dos $S S$, mas, sobretudo da incapacidade de resistir ao próprio sistema de funcionamento da maquinaria estatal nazista, na medida em que a cooperação das vítimas era exigida pela necessidade de salvarem a si mesmos da morte, sob o argumento de amenizar as atrocidades que "poderiam" ser cometidas. Ou seja, a manutenção e 
continuidade do "moinho de morte" do estado nazista era o constante privilégios concedidos àqueles que contribuiriam com o sistema, na qualidade de exceção, justificando, desta forma, toda a regra envolvendo de liquidação da "raça inferior".

Ainda, quanto ao Conselho Judeu Central, órgão de colaboração com o Estado Nazista, Hannah Arendt descreve que os funcionários judeus, ao se transformarem em instrumentos de assassinatos, se sentiam semelhante a salvadores que "com cem vítimas salvam mil pessoas, com mil salvavam 10 mil" (Arendt, 1999, p. 135), de modo a se convencerem de sua necessidade para não deixarem a seleção a cargo do "destino cego", na medida em que utilizaram princípios sagrados como força guia para a fraca mão humana que registra no papel o nome de uma pessoa desconhecida e com isso decide sobre sua vida ou sua morte (Arendt, 1999, p. 135).

Sobre a colaboração dos judeus ao extermínio de seu próprio povo, Hannah Arendt (1999, p. 139), fazendo referência às testemunhas ouvidas no julgamento de Eichmann, relata que:

$\mathrm{O}$ fato bem conhecido de que o trabalho direto dos centros de extermínio ficava usualmente nas mãos dos comandos judeus foi justa e cabalmente esclarecido pelas testemunhas de acusação - como trabalhavam nas câmaras de gás e nos crematórios, como eles arrancavam os dentes de ouro e cortavam o cabelo dos mortos, como eles cavavam os túmulos e os desenterraram de novo para eliminar os traços do assassinato em massa; como os técnicos judeus haviam construído as câmaras de gás em Theresienstadt, aonde a autonomia dos judeus havia sido levada tão longe que até o carrasco era judeu.

Observa-se, dessa forma, seja qual for à circunstância do privilégio, a violência causada pela ausência de sentido das relações, resultante da incapacidade de análise das referências ao campo simbólico ou do campo das estruturas significantes, leva-nos a análise em termos de genealogia das relações de força, implicando, assim, em desenvolvimento estratégico, qual seja, da sobrevivência, ou da satisfação de certos desejos.

Em análise às lições de Foucault, as relações no Lager são relações de poder, e não de uma relação de sentido (Foucault, 2015, p. 41), o que implica, no que se refere à violência das relações entre os prisioneiros comuns, os prisioneiros privilegiados, e os soldados $S S$, em uma violência sem sentido para aquele que a sofre, cujo único significado, diga-se, alheio a condição cognitiva do prisioneiro, ou daquele que sofre a violência, diante 
de sua incapacidade de atribuir sentido, é, exatamente, destruir toda e qualquer capacidade de reação e luta às relações de poder.

No que concerne às relações de poder, Foucault descreve que o seu sentido é indefinidamente o mesmo, o da dominação, onde se observa os dominadores e os dominados. Homens dominam uns aos outros, e assim nasce a diferença dos valores; classes dominam classes, e assim nasce a ideia de liberdade; homens se apoderam de coisas das quais eles tem necessidade para viver, ele lhe impõe uma duração que elas não têm, ou eles o assimilam pela força, e assim nasce a lógica (Foucault, 2015, p. 68).

A necessidade de se apoderar de uma porção do poder sobre os demais corpos do Lager, dentro de uma relação de domínio, é estabelecida pela necessidade de sobrevivência, a partir da concessão de ração extra de alimento, necessária à manutenção mínima, ou mais prolongada, da existência do próprio corpo.

Segue lecionando o autor francês:

Nem a relação de dominação é mais uma relação, nem o lugar onde ela se exerce é um lugar. E é por isso precisamente que em cada momento da história a dominação é fixada em um ritual; ela impõe obrigações e direitos; ela constitui cuidadosos procedimentos. Ela estabelece marcas, grava lembranças nas coisas e nos corpos; ela se torna responsável pelas dívidas. Universo de regras que não é destinado a adoçar, mas, ao contrário, de satisfazer a violência. Seria um erro acreditar, segundo esquema tradicional, que a guerra geral, se esgotaria em suas próprias contradições, acaba por renunciar à violência e aceita sua própria supressão nas leis de paz civil. A regra é o prazer calculado da obstinação, é o sangue prometido. Ela permite reativar sem cessar o jogo da dominação; ela põe em cena uma violência meticulosamente repetida. O desejo da paz, a doçura do compromisso, a aceitação tácita da lei, longe de serem a grande conversão moral ou o útil calculado que deram nascimento à regra, são apenas seu resultado e propriamente sua perversão: "Falta, consciência, o dever tem sua emergência no direito de obrigação; e em seu começo, como tudo o que é grande sobre a terra, foi banhado em sangue". A humanidade não progride lentamente, de combate em combate, até uma reciprocidade universal, em que as regras substituíram para sempre a guerra; ela instala cada uma de suas violências em um sistema de regras e prossegue, assim, de dominação em dominação (Foucault, 2015, p. 68-69).

A análise de Foucault é fundamental à compreensão da finalidade de todo o sistema normativo do Lager, em especial o ritual de recepção dos "novatos", ou seja, da violência na chegada dos prisioneiros ao campo, 
institucionalizada nas normas do campo, cuja finalidade é expropriar toda e qualquer capacidade de resistência na dominação, e, assim, ao final de todo o processo, ou seja, do ritual, o prisioneiro, seja ele comum ou privilegiado, encontra-se completamente docilizado.

Ainda, é clara a crítica de Foucault sobre a forma contratual da norma, crítica essa já lançada no início do presente trabalho, sobre a forma contratual vazia, desprovida de uma substância essencial. É justamente a regra que permite que seja feita a violência a violência e que outra dominação possa dobrar aqueles que o dominam. Em si mesmas, as regras são vazias, violentas, não finalizadas; são feitas para servir a isto ou aquilo; elas podem ser burladas ao sabor da vontade de uns ou de outros. O grande jogo da história será de quem se apoderar das regras (Foucault, 2015, p. 69).

Assim, o "cinza" da vivência no campo, um ambiente infernal cujo sistema condiciona ferreamente os comportamentos, na medida em que em poucas semanas ou meses, as privações a que foram submetidos, os conduziram a condição de pura sobrevivência, de luta cotidiana contra a fome, o frio, a fadiga, o espancamento, o espaço para as escolhas (especialmente para as escolhas morais) estava reduzido ao nada. Ou seja, a barbárie e o horror em sua mais ampla dimensão, consolidaram a substância das normas do Lager, destruindo, desta forma, toda e qualquer capacidade de reação, não só da violência física, mas, da própria alma do prisioneiro.

Toda a sistemática do campo, ou seja, sua estrutura (a)normal, exceptio, excepcional, implica no desaparecimento do desconforto, do malestar da submissão às condições do Lager, sobrevindo, assim, o "costume", que, segundo Levi (2004, p. 97), "é um modo caridoso de dizer que a transformação de seres humanos em animais já estava no meio do caminho", sendo esta transformação consolidada na figura do muçulmano, uma outra representação extrema do campo.

Ao testemunhar sobre os muçulmanos ${ }^{4}$, Levi (1988, p. 132) descreve que são os

4 Designação feita pelos veteranos do campo, dos fracos, os ineptos, os destinados à seleção (Levi, 1988, p. 129). Trata-se daqueles que em razão do esgotamento físico e mental, dada as ínfimas rações alimentares, trabalhos excessivos e doenças, macilento, cabisbaixo, de ombros curvados, em cujo o rosto, em cujo olhar, não se possa ler o menor pensamento (Levi, 1988, p. 132). 
submersos, são eles a força do campo: a multidão anônima, continuamente renovada e sempre igual; já se apagou neles a centelha divina, já estão tão vazios, que nem podem realmente sofrer. Hesita-se chama-los de vivos; hesita-se chamar de "morte" à sua morte, que eles já nem temem, porque estão esgotados demais para poder compreendê-la.

Os muçulmanos representam a transfiguração consolidada, anteriormente mencionada, de seres humanos em animais, resultante de toda sistemática (a)normativa do Lager, que por sua vez, é causada pela inútil crueldade do pudor violado que condicionava a vida no campo.

Essa sombria, perversa e horrenda consequência, não teria sido, segundo Levi, projetada explicitamente, em nenhum nível de hierarquia nazista, em nenhum documento ou "reunião de trabalho, mas consequência lógica do sistema de um regime desumano que difunde e estende sua desumanidade em todas as direções” (2004, p. 97), um mal banal, burocrático, "que não tem profundidade, mas que pode destruir o mundo em razão da incapacidade de pensar das pessoas, capaz de espraiar-se pela superfície da terra como um fungo" (Lafer, 2006, p. 26).

\section{O CAMPO COMO UM PARADOXO NORMATIVO}

Diante de todo o panorama até então estabelecido, em especial, da existência de toda uma estrutura sistemática que tenha proporcionado a barbárie ora denunciada, capaz de ocasionar a morte da alma antes do padecimento do corpo, cumpre-nos questionar, em razão do objeto de investigação da presente pesquisa, qual o papel que o Direito, enquanto instrumento de tutela e de garantias, desempenhou nesse trágico episódio da história da humanidade? Ora, em que medida é possível pensar a existência dos Lagers, ou seja, dos campos de extermínio, concomitantemente com a existência do Direito, em especial, dos Direitos Humanos?

A fim de esclarecer a problemática apresentada, há de se destacar que o estado nazista se consolidava em um Estado de Direito, uma vez que, ao tempo da ascensão do nazismo, e, ainda, dos campos de extermínio, vigia a Constituição de Weimar, imposta à Alemanha pelos próprios Aliados ao final da Primeira Guerra Mundial. 
Assim, tão logo o poder fora "entregue" a partido nazista, Hitler promulgou o Decreto para a proteção do povo e do Estado, que suspendia os artigos da Constituição de Weimar relativos às liberdades individuais, com fundamento na própria constituição, tendo por fundamento legal o artigo $48^{5}$, que previa a possibilidade de suspensão dos direitos fundamentais nos casos em que a segurança e a ordem pública estivessem ameaçadas.

Observa-se, nesse sentido, que os doze anos em que o estado nazista esteve à frente do poder, como regime totalitário, instaurado por meio do estado de exceção, implica na conclusão paradoxal de uma guerra civil legal, “onde há a permissão de eliminação física não só dos adversários políticos, mas, também, de categorias inteiras de cidadãos que, por qualquer razão pareçam não integráveis ao sistema político” (Agamben, 2004, p. 13).

Dessa forma, para trazer algum sentido aos questionamentos anteriormente apresentados, há que se destacar qual a significação que o campo representa na discussão sobre a relação entre o jurídico-político.

Quanto a esse aspecto, identifica-se, desde já, o campo enquanto forma legal daquilo que não pode ter forma legal, ou seja, como espaço de exceção normativa-jurídica, um dispositivo original ao qual o direito se refere à vida e a inclui em si por meio de sua própria suspenção, revelando uma relação que liga e, ao mesmo tempo, abandona o vivente ao direito (Agamben, 2004, p. 12).

Giorgio Agamben propõe, com a definição anteriormente mencionada, que o campo de extermínio se apresenta como uma circunstância ambígua, e, portanto, paradoxal, em que se observa a vigência

5 Artikel 48. Wenn ein Land die ihm nach der Reichsverfassung oder den Reichsgesetzen obliegenden Pflichten nicht erfüllt, kann der Reichspräsident es dazu mit Hilfe der bewaffneten Macht anhalten.

Der Reichspräsident kann wenn im Deutschen Reiche die öffentliche Sicherheit und Ordnung erheblich gestört oder gefährdet wird, die zur Wiederherstellung der öffentlichen Sicherheit und Ordnung nötigen Maßnahmen treffen, erforderlichenfalls mit Hilfe der bewaffneten Macht einschreiten. Zu diesem Zwecke darf er vorübergehend die in den Artikeln 114, 115, 117, 118, 123, 124 und 153 festgesetzten Grundrechte ganz oder zum Teil außer Kraft setzen

Von allen gemäß Abs. 1 oder Abs. dieses Artikels getroffenen Maßnahmen hat der Reichspräsident unverzüglich dem Reichstag Kenntnis zu geben. Die Maßnahmen sind auf Verlangen des Reichstags außer Kraft zu setzen.

Bei Gefahr im Verzuge kann die Landesregierung für ihr Gebiet einstweilige Maßnahmen der in Abs.2 bezeichneten Art treffen. Die Maßnahmen sind auf Verlangen des Reichspräsidenten oder des Reichstags außer Kraft zu setzen.

Das Nähere bestimmt ein Reichsgesetz. 
e a suspensão, diga-se, concomitante, da norma jurídica, a qual se se revela pela aplicação por sua desaplicação, e, consequentemente, em uma exclusão includente do vivente.

A fim de exemplificar, Agamben esclarece que:

O significado imediatamente biopolítico do estado de exceção como estrutura original em que o direito inclui em si o vivente por meio de sua própria suspensão aparece claramente na "military order", promulgada pelo presidente dos Estados Unidos no dia 13 de novembro de 2001, e que autoriza a "indefinite detention" e o processo perante as "military commissions" (não confundir com os tribunais militares previstos pelo direito da guerra) dos não cidadãos suspeitos de envolvimento em atividades terroristas (Agamben, 2004, p. 14).

Observa-se, claramente, no exemplo acima transcrito, que a ordem política do Chefe de Estado (Soberano), acaba por anular, radicalmente, todo o estatuto jurídico do indivíduo, colocando-o, ainda, a mercê do Estado, na medida em que esse, ao mesmo tempo em que anula seus direitos políticos, pondo-o, assim, para fora do circuito jurídico, o captura fora do respectivo circuito, produzindo, dessa forma, uma figura juridicamente inominável e inclassificável, uma vez que não é mais possível classificá-lo, do ponto de vista jurídico, como pessoa ou sujeito de direito.

A partir dessa ideia, abre-se a problemática da despersonalização jurídica dos judeus, que em sua maioria compunham os campos de extermínio. Em 1935, duas medidas foram anunciadas pelo estado nazista, em Nuremberg, tornando-se conhecido como as Leis de Nuremberg. A segunda dessas medidas, a "Lei de cidadania do Reich", declarou que aqueles que não pertenciam à "raça ariana", não eram cidadãos para assuntos do Estado, ou seja, não eram cidadãos do Reich. Veja-se que a respectiva medida política-jurídica acaba, via de consequência, por retirar dos judeus a qualidade de cidadãos, motivo pelo qual não se aplicariam aos mesmos todo aparato de garantias jurídicas do Reich.

A medida jurídico-política acima mencionada revela que o estado nazista coloca aqueles que não são considerados cidadãos do Reich em uma zona (espaço) indecifrável do ponto de vista jurídico, pois, não sendo cidadãos, ou seja, não estando incluídos em uma relação sujeito-Estadonação, não há, via de consequência, a possibilidade de qualificação e tutela 
jurídica de suas vidas, na medida em que não há mais personalidade jurídica.

Diante do cenário apresentado, um questionamento se mostra necessário à compreensão do estado nazista como um Estado de Direito, e, ainda, como os campos de extermínio existiram concomitantemente com direito, a saber: qual a legitimidade, jurídica, do chefe do executivo, em editar as medidas que retiraram dos judeus a sua condição de cidadão, e, consequentemente, sua personalidade jurídica, ou seja, qual o fundamento da autoridade política?

Observa-se que o questionamento apontado exige uma problematização acerca do direito de governar, e, em razão dos referenciais teóricos que orientam o presente trabalho, há a necessidade de revisitar uma das narrativas fundantes da modernidade: a teoria do contrato social.

Como é sabido, esta matriz teórica proporciona grande inteligibilidade da política moderna, provendo o fundamento e a legitimação para as relações de domínio, as diferenças entre mando e obediência, que constituem a base da soberania, do Direito e do Estado. O mitologema do contrato, empregado por Giorgio Agamben, indica o atrelamento das categorias fundamentais do pensamento político à figura do Estado, entendido como organização jurídica da civitas, como pacto de união e submissão (Giacoia Jr., 2014, p. 50).

É nesse ponto que Giorgio Agamben ataca o mito do pacto social enquanto fundamento do direito de governança, e, consequentemente, da autoridade política. Nesse sentido, a relação entre o jurídico e o político não encontram suas bases na proposta do consentimento, ou seja, do contrato, antes o contrário, a figura matricial do relacionamento jurídico-político originário é o bando ${ }^{6}$.

Agamben estabelece que somente é possível pensar o instituto da pena, e, via de consequência, da organização jurídica da sociedade (civitas), a partir do paradoxo da exceção como estrutura e verdade da norma, dada a

6 Segundo as lições do Professor Oswaldo Giacoia Júnior (2008), Bando é a tradução portuguesa do termo alemão Bann, que significa o poder de governo, a soberania, o direito de estatuir comandos e proibições, de impor e executar penas; também o direito de banir. Como conceito, mantém íntima relação com o instituto da Friedlosigkeit do antigo direito germânico e a correspondente figura do Friedlos, que designam a condição daquele que, banido e proscrito, está excluído da esfera de proteção do ordenamento jurídico da comunidade de origem, e, portanto, impossibilitado de gozar do privilégio da paz assegurada por esse ordenamento. Nesse sentido, o Friedlos é o sem paz, o exposto às forças da natureza e à violência arbitrária de quem quer que seja. 
relação necessária existente entre direito, força e poder, pelo viés da soberania, o que desabilita a interpretação prevalecente da sociabilidade, mediante a admissão da violência como fato jurídico primordial, fazendo por revelar a estrutura originária na qual o direito se refere à vida e a inclui em si mesmo através de sua própria suspensão (Agamben, 2002, p. 35).

Segundo Agamben (2002 p. 116), aquele que foi posto sob o Bando é, então, remetido à própria separação e, com isso, à mercê de quem o abandona, sendo, ao mesmo tempo, excluído e incluído, dispensado e, simultaneamente, capturado, fazendo por concluir, no paradigma do jurídico-político, pela possibilidade da expropriação das categorias e atributos de qualificam o indivíduo enquanto homem e cidadão, por intermédio de uma decisão soberana, revelando a figurado do Homo Sacer, sendo esse o condenado cuja a morte não constitui nem sacrifício nem homicídio, portando aquele excluído tanto da esfera do direito divino e do direito humano. Nesse sentido, bando e exceptio exibem analogia estrutural, pois na medida em que a exceção significa a captura daquele que foi posto para fora do circuito de direito próximo do banimento.

A relação de abandono é, de fato, tão ambígua, que nada
é mais difícil do que desligar-se dela. O bando é
essencialmente o poder de remeter algo a si mesmo, ou
seja, o poder de manter-se em relação com um irrelato
pressuposto. O que foi posto em bando é remetido à
própria separação e, juntamente, entregue à mercê de
quem o abandona, ao mesmo tempo excluso e incluso,
dispensado e, simultaneamente, capturado (Agamben,
2002, p. 116).

Assim, o banimento seria um desligamento subsequente ao descumprimento da obligatio, que vincula os membros da comunidade às seus usos e costumes, o qual traz consigo o sentido de que a expulsão da esfera dos costumes, onde reinam a ordem e a paz. O bando corresponde à condição do "sem-paz", àquele que é colocado para fora da lei, condição esta que coloca o infrator à exposição da violência e ao arbítrio das forças naturais e humanas (Nietzsche, 2009, p. 78-79).

O que é colocado em questão, a partir da relação estrutural entre bando e exceção (exceptio, ex capere, 'capturar fora'), é toda a proposta de fundamentação do direito, no Estado Moderno, fundada no pacto de submissão, pois, em um exercício hermenêutico mais aprofundado, a fim de darmos conta da problemática levantada no presente debate, teremos que 
deixar de considerar as declarações de direitos fundamentais como proclamação de valores eternos e metajurídicos, para dar conta de sua função histórica real, como dispositivo de inserção da vida no campo de incidência da decisão soberana. Inclui-se ao o dogma da sacralidade da vida que, sob a forma das declarações de direitos do homem e do cidadão, que inspira as constituições republicanas (Giacóia Jr., 2014, p. 51).

Ora, se de fato o que define a soberania é a prerrogativa (normativa) de decidir sobre a suspensão do ordenamento jurídico-estatal, então o soberano é, no primeiro momento de análise, aquele a quem a lei se aplica por suspensão de sua aplicação; soberano é aquele que, por força de uma prerrogativa constitucional, pode decretar a suspensão total ou parcial da constituição dos direitos e garantias nela consolidados. Trata-se, portanto, da suspensão da ordem jurídica por intermédio de uma decisão política (Giacóia Jr., 2014, p. 51), possibilitando, portanto, a suspensão da garantia dos direitos do homem e do cidadão, conforme, inclusive, as proposições de Carl Schmitt ${ }^{7}$ quanto à soberania, inserindo, assim, o indivíduo, que era sujeito de direito, na vida nua, ou seja, a vida desqualificada, tal qual ocorreu com os prisioneiros dos campos de concentração.

Essa discussão torna-se tão séria e, ainda mais emergente, à medida que se entende os direitos do homem e do cidadão em uma perspectiva de direitos inalienáveis, imprescritíveis, posto que encontram fundamento na própria concepção de homem e na concepção de soberania nacional, da ideia de emancipação de um povo no sentido de atribuir a ele às questões do governo.

Essa "linha de força" na apreciação e avaliação dos campos de concentração - no passado e no presente - aponta à necessidade de verificação dos mecanismos que possibilitam a existência de espaços desprovidos de regulamentação normativa, ou seja, espaços de exceção, que acabam por proporcionar figuras como o muçulmano, o Homo Sacer ${ }^{8}$, a vida matável.

7 Quanto ao conceito de soberania em Carl Schmitt, sugestiona-se a leitura do texto Teologia Política, posto que, muito embora o problema da soberania tenha uma relação direta com a presente discussão, não constitui objeto de análise, em específico, da presente pesquisa.

8 Trata-se da figura do Homem sacro é, portanto, aquele que o povo julgou por um delito; e não é lícito sacrificá-lo, mas quem o mata não será condenado por homicídio; na verdade, na primeira lei tribunícia se adverte que 'se alguém matar aquele que por plebiscito é 
Hannah Arendt, revela, de maneira pontual, que a problemática do estado de exceção relaciona-se, diretamente, com a perda de um espaço de pertencimento, de modo que a "calamidade dos que não têm direitos não decorre do fato de terem sido privados da vida, da liberdade, ou da procura da felicidade, nem da igualdade perante a lei ou da liberdade de opinião, mas do fato de não pertencerem a qualquer comunidade" (ARENDT, 2012. p. 402).

Em leitura minuciosa, o Professor Ricardo Fonseca identifica os passos de Agamben a partir do projeto de Hannah Arendt quanto à necessidade, em termos de tutela jurídica, do pertencimento a uma comunidade política, ou seja, na existência do Estado como garante e "força pública”, na medida que os direitos devem ser aferidos, numa relação indivíduo-Estado-nação, sem intermediários:

Ou seja: o sujeito tem direitos enquanto pertencente a um determinado Estado-Nação, que o protege a partir das garantias e direitos estabelecidos em seus documentos jurídicos (derivados de sua soberania). O que faz com que surja inevitavelmente a indagação sobre como fica a tutela dos direitos daqueles (que se tornam cada vez mais numerosos ao longo do século XX), que não estão sob a proteção de nenhum Estado-Nação (Fonseca, 2011, p. 286).

Nesse sentido, o campo de concentração é o resultado do confisco da cidadania e nacionalidade, transformando a vida de seus internos em vida desqualificada, "vida nua”, já que nenhuma tutela jurídica se mostra possível, resultando, apenas, em objeto de poder, do resultado da biopolítica, da estrutura política de governo (Fonseca, 2011, 286).

Tendo em vista que estrutura primária do Estado moderno exige o pertencimento a certa comunidade política, qualificando, dessa forma, o vivente em pessoa, sendo assim, titular de direitos reconhecidamente garantidos pela ordem jurídica, aquele que não é reconhecido como tal, ou seja, que foi excluído da comunidade política, encontra-se incluído em uma zona (espaço) de anormalidade, revelando, dessa forma, a ação da exclusão includente, ou seja, do estado de exceção que se afigura nos campos de concentração.

sacro, não será considerado homicida'. Disso advém que um homem malvado ou impuro costuma ser chamado sacro (Agamben, 2002, p. 196). 
A barbárie vivenciada na segunda guerra mundial, com os campos de extermínio, revela-se na figura mais extrema do estado de exceção, e que é resultado da assunção do poder na função de gerir a vida via dispositivo, em especial, o dispositivo jurídico enquanto garantidor e força pública da tutela da vida coletiva, o que revela o paradoxo do direito como instrumento de gestão e organização da vida social, uma vez que a "regra" existe em razão de sua exceção.

\section{CONSIDERAÇÕES FINAIS}

A segunda guerra mundial apresenta-se como um acontecimento paradigmático na história da humanidade, em especial quanto à discussão sobre o Homem, o jurídico e o político, a partir dos campos de concentração.

Em grande medida, a pesquisa demonstra a impossibilidade de separação do direito da política, de modo que, o campo de concentração (espaço de exceção), é o resultado desse liminar, dessa zona de indecidibilidade entre o direito e a política, eliminando, dessa forma, toda e qualquer tentativa de explicação dos fenômenos humanos a partir de arguições sectárias que acabam, necessariamente, desprezando o contexto integral da história.

Assim, a existência de "Auschwitz" enquanto fenômeno histórico revela a fragilidade do debate acerca da atuação jurídica e política contemporâneas, quanto à fundamentação do direito e da política pela dignidade da pessoa humana, na medida em que há uma relação íntima e necessária entre a definição (decisão política) sobre o que de direito, a aplicação do direito, e, ainda, a própria suspensão do direito, evidenciando, a impossibilidade de reconhecimento de um conteúdo substancial jurídico por si mesmo, pautado na ideia de essência ou natureza humana, firmando o entendimento já anunciado por Hannah Arendt sobre o fim dos direitos humanos.

Ora, considerando a necessidade de pertencimento do vivente à comunidade política (Estado) para que o mesmo possa estar submetido a uma ordem jurídica, e, assim, adquirir personalidade jurídica, o direito enquanto garantidor das condições entendidas como "necessárias a uma vida digna”, encontra um elemento essencialmente político, a saber: a 
cidadania, pondo em cheque a proposta dos direitos humanos como direitos inatos e inalienáveis, na medida em que passa a ser possível a existência de seres humanos que não pertencem a nenhuma comunidade política, o que é evidenciado na figura dos refugiados e dos apátridas, condições estas se assemelham a dos prisioneiros dos campos de concentração. Observa-se, assim, um Ser Humano que não tem direitos humanos, por não estar submetido a nenhum Estado-nação, estando, assim, inserido dentro de um estado de exceção.

A ressignificação do fundamento da autoridade política que estrutura os Estados modernos, a partir do instituto do bando, em contraposição ao mito do contrato, numa inversão radical da tradição jus filosófica, permite a identificação, paradoxal, da exceção, como estrutura e verdade da norma, uma imbricação, necessária, entre direito, força e poder pelo viés da soberania; o que desabilita a interpretação prevalente e recorrente da existência de uma substância normativa, fundada na natureza humana, legítima e aplicável em si mesma.

À luz dessa relação, o campo de concentração, na forma da exceção, define-se a partir de uma "estrutura originária na qual o direito se refere à vida, e a inclui em si através de sua própria suspensão” (Agamben, 2002, p. 35), fazendo por concluir que o campo, de forma espectral, é o resultado da operação do direito e da política via dispositivo.

\section{REFERÊNCIAS}

AGAMBEN, Giorgio. O que resta de Auschwitz: o arquivo e a testemunha; Homo Sacer III. Trad. de Selvino J. Assmann. São Paulo: Boitempo, 2008.

AGAMBEN, Giorgio. Homo Sacer: o poder soberano e a vida nua I. Trad. de Henrique Burigo. Belo Horizonte: Editora UFMG, 2002.

AGAMBEN, Giorgio. Estado de exceção: Homo Sacer II. Trad. de Iraci D. Poleti. São Paulo: Boitempo, 2004.

ARENDT, Hannah. Eichmann em Jerusalém. Trad. de José Rubens Siqueira. São Paulo: Companhia das Letras, 1999.

BUENO, Roberto. Barbárie: literatura e filosofia moral. Boletim Mexicano de Derecho Comparado, nueva serie, n. 137, p. 471-498, mayo-ago. de 2013.

BUENO, Roberto. $O$ papel da literatura na reconstrução das subjetividades. Em tempo, Marília, v. 10, p. 9-25, 2011.

GIACÓIA JÚNIOR, Oswaldo. Nietzsche: o humano como memória e como promessa. Petrópolis: Vozes, 2013. 
GIACÓIA JÚNIOR, Oswaldo. Sobre direitos humanos na era da biopolítica. Kriton - Revista de Filosofia, Belo Horizonte, v. 49, n. 118, p. 267308, dez. 2008.

GIACÓIA JÚNIOR, Oswaldo. Estado, democracia e sujeito de direito: para uma crítica da política contemporânea. Revista de Filosofia Moderna e Contemporânea, Brasília, v. 2, n. 2, p. 49-61, 2014.

FONSECA, Ricardo Marcelo. Para uma possível teoria da história dos direitos humanos. Pensar, Fortaleza, v. 16, n. 1, p. 273-291, jan./jun. 2011.

FOUCAULT, Michel. Microfísica do poder. Organização, introdução e revisão de Roberto Machado. 2. ed. Rio de Janeiro: Paz e Terra, 2015.

GINZBURG, Jaime. Linguagem e trauma na escrita do testemunho. Revista Conexão Letras, V. 3, n. 3, p. 19-32, 2008.

LAFER, Celso. A internacionalização dos direitos humanos: o desafio do direito a ter direitos. In: AGUIAR, O. A. et alii (Org.). Filosofia e direitos humanos. Fortaleza: Editora da Universidade Federal do Ceará, 2006. p. 13-32.

LEVI, Primo. É isto um homem? Trad. de Luigi Del Re. Rio de Janeiro: Rocco, 1988.

LEVI, Primo. Afogados e sobreviventes. Trad. de Luiz Sérgio Henriques. São Paulo: Paz e Terra, 2004.

NIETZSCHE, Friedrich Wilhelm. A genealogia da moral. Trad. de Antônio Carlos Braga. 3. ed. São Paulo: Escala, 2009.

RAMIRO, Caio Henrique. Direito, literatura e a construção do saber jurídico: Paulo Leminski e a crítica do formalismo jurídico. Revista de Informação Legislativa, Brasília, n. 196, p. 267-309, out./dez. 2012.

PIETROFORTE, Antônio Vicente Serafhim. O discurso jurídico através do discurso poético. Em tempo, Marília, n. 4, p. 24-33, ago. 2002.

SELIGMANN-SILVA, Márcio. Apresentação da questão. In: SELIGMANNSILVA, Márcio (Org.). História, memória, literatura. Campinas: Unicamp, 2003. p. 45-58.

Idioma original: Português

Recebido: 20/11/17

Aceito: 04/04/18 